\title{
The dounrmal of
}
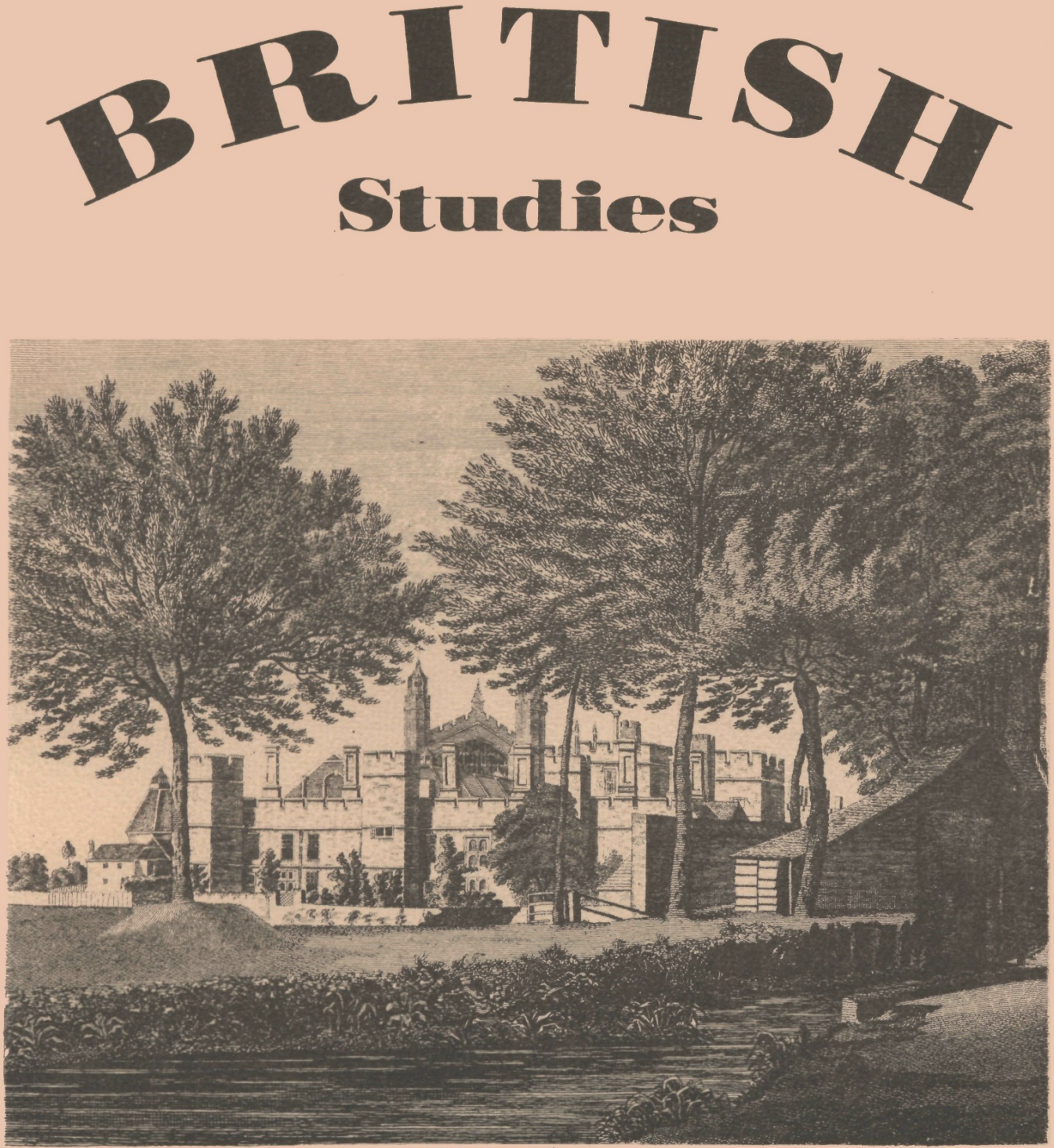

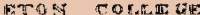

\section{SPRING 1979}




\section{From the library of Peter Stansky}

Bentley B. Gilbert, unvversuy of sumvow un Chicago Circle

\section{ASSOCIATE EDITORS}

Peter Stansky, Stanford University

David Roberts, Dartmouth College

David Underdown, Brown University
NG EDITOR

Cooper, Trinity College
Shyla Spear

BUSINESS MANAGER

Patricia A. McDonald

\section{BOARD OF ADVISORS}

H. J. Hanham, Massachusetts Institute of Technology

Gertrude Himmelfarb, Graduate Center, City University of New York

Maurice Lee, Jr., Douglass College, Rutgers University

F. M. Leventhal, Boston University

Bryce Lyon, Brown University

W. T. MacCaffrey, Harvard University
Helen F. Mulvey, Connecticut College Jacob M. Price, University of Michigan

Bernard Semmel, State University of New York, Stony Brook

Barbara Shapiro, University of California, Berkeley

Robert A. Smith, Emory University

Robin W. Winks, Yale University

\section{OVERSEAS CORRESPONDENTS}

Barbara Harvey, Somerville College, Oxford

Harold Perkin, University of Lancaster

Keith Thomas, St. John's College, Oxford

\section{CONFERENCE ON BRITISH STUDIES}

\section{PRESIDENT}

Lacey Baldwin Smith, Northwestern University

ASSOCIATE EXECUTIVE SECRETARY

Reba N. Soffer, California State University, Northridge

RECORDING SECRETARY

Esther Cope, University of Nebraska
EXECUTIVE SECRETARY

Jacob M. Price, University of Michigan, Ann Arbor

TREASURER

Stuart E. Prall, Queen's College, C.U.N.Y. PROGRAM CHAIRMAN

Anthony Wohl, Vassar College
Inquiries concerning membership in the Conference on British Studies and individual subseriptions to the Journal of British Studies (two issues a year, Fall and Spring) should be addressed to Professor Stuart Prall, Department of History, Queen's College, C.U.N.Y., Flushing, New York 11367.

Contributors should send two copies of their manuscripts along with return postage to the
Editor-Designate, Bentley B. Gilbert, Department of History, University of Illinois at Chicago Circle, Chicago, Illinois 60680.

COVER: A view of Eton College, by Paul Sandby, engraved by W. Godfrey, 1766. Reproduced by kind permission of the Lewis Walpole Library, Farmington, Connecticut. 


\section{The Journal of BRITISH Studies}

\begin{tabular}{|c|c|c|}
\hline Vol. XVIII & Spring 1 & 1979 \\
\hline \multicolumn{3}{|c|}{ CONTENTS } \\
\hline Author & Title & Page \\
\hline CHARLES T. WOOD & $\begin{array}{l}\text { The English Crisis of } 1297 \text { in the Light } \\
\text { of French Experience }\end{array}$ & It 1 \\
\hline JAMES L. GILLESPIE & Richard II's Archers of the Crown ............... & 14 \\
\hline RONALD W. HERLAN & $\begin{array}{l}\text { Poor Relief in London during the English } \\
\text { Revolution }\end{array}$ & 30 \\
\hline F. G. JAMES & $\begin{array}{l}\text { The Active Irish Peers in the Early Eigh- } \\
\text { teenth Century }\end{array}$ & 52 \\
\hline IAIN HAMPSHER-MONK & 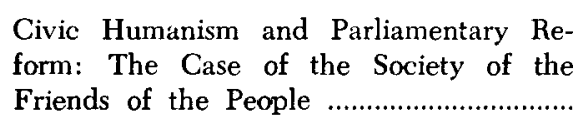 & e \\
\hline CARLA H. HAY & $\begin{array}{l}\text { The Making of a Radical: The Case of } \\
\text { James Burgh }\end{array}$ &. .90 \\
\hline JAMES E. CRONIN & $\begin{array}{l}\text { The Peculiar Pattern of British Strikes } \\
\text { since } 1888\end{array}$ & .. 118 \\
\hline
\end{tabular}

Review Articles:

MARGARET HASTINGS and Two Distinguished Medievalists - Nellie ELISABETH G. KIMBALL Neilson and Bertha Haven Putnam .......... 142 STEPHEN D. WHITE Observations on Early Stuart Parliamentary History .................................................... 160

DAVID UNDERDOWN The Harringtonian Moment .................... 171

Published by

The Conference on British Studies at Trinity College, Hartford, Connecticut Copyright 1979 by the Conference on British Studies at Trinity College, Hartford, Connecticut. Printed in the U.S.A. at The Bond Press, Inc., Hartford, Connecticut. 


\section{NOTES ON CONTRIBUTORS}

JAMES E. CRONIN is Assistant Professor of History at the University of Wisconsin-Milwaukee. His book, The Dynamics of Industrial Conflict in Britain, 1888-1974, is scheduled for publication this fall. Current research includes a comparative study of social conflict in Europe during the early twentieth century.

JAMES L. GILLESPIE is Assistant Professor of History at Catawba College. He has written several articles on Richard II -in Albion (1975) and The Historian (1978) - and is now working on a translation and edition of Thomas Otterbourne's Chronicle.

IAIN HAMPSHER-MONK is Lecturer in the Department of Politics, University of Exeter, England. He has written on the Levellers in Political Studies (1976) and on Locke in the Journal of the History of Ideas (1979). Current research concerns Burke and the English reaction to the French revolution.

MARGARET HASTINGS is Emeritus Professor of History, having taught at Douglass College, Rutgers University for many years. Her publications include The Court of Common Pleas in Fifteenth Century England (1947) and High History or Hack History (1962). She is now working on Thomas More as a lawyer, in particular his career as Chancellor of the Duchy of Lancaster.

CARLA H. HAY is Assistant Professor of History at Marquette University. Her art:cle, "Benjamin Franklin, James Burgh, and 'The Colonist's Advocate' Letters," appeared in the William and Mary Quarterly (1975). An intellectual biography of Burgh is now in press. She is writing a biography of Catharine Macaulay and is also completing research on a study of John Sawbridge and 'popular politics' in late eighteenth-century London.

RONALD W. HERLAN is Assistant Professor of History at State University College at Brockport, New York. He has published two articles on parochial poverty and poor relief in seventeenth-century London in Guildhall Studies in London History $(1976,1977)$ and is now writing an essay entitled "Poor Relief in the Bristol Parish of Temple in the Age of the Early Stuarts and the English Revolution."

FRANCIS G. JAMES is Professor of History at Newcomb College, Tulane University. His books include North Country Bishop: A Biography of William Nicolson (1956) and Ireland in the Empire, 1688-1770 (1973), and he has written two articles on eighteenth-century Ireland in the William and Mary Quarterly (1963) and the English Historical Review (1966). He is now working on the Irish House of Lords from 1660 to 1800.

ELISABETH G. KIMBALL has retired from the Educational Testing Service in Princeton. She has published Serieanty Tenure in Medieval England, Rolls of the Warwickshire and Coventry Sessions of the Peace, 1377-1397, and other records of the justices of the peace in the fourteenth and fifteenth centuries.

DAVID UNDERDOWN is Munroe-Goodwin-Wilkinson Professor of History at Brown University. His books include Royalist Conspiracy in England 164960 (1960), Pride's Purge (1971), and Somerset in the Civil War and Interregnum (1973). His articles have appeared in the English Historical Review, Past and Present, and J.B.S. At present he is working on a comparative study of regional allegiance in the English civil wars.

STEPHEN D. WHITE is Assistant Professor of History at Wesleyan University. He has recently published Sir Edward Coke and "The Grievances of the Commonwealth." 1621-1628 (1979); and his articles include "Succession to Fiefs in Early Medieval England," Past and Present (1974) and "English Feudalism and Its Origins," American Journal of Legal History (1975). He is now doing research on methods of settling disputes in northern France and England during the eleventh and twelfth centuries.

CHARLES T. WOOD is Professor and Chairman of the Department of History at Dartmouth College. His books include The French Apanages and the Capetian Monarchy 1224-1328 (1966), The Age of Chivalry: Manners and Morals 1000-1450 (1970), and Philip the Fair and Boniface VIII (2nd ed., 1976). Among his articles on English historical topics are "The Deposition of Fdward V" Traditio (1975) and "The Right to Rule in England ... 1327-1485," (with William H. Dunham, Jr.) American Historical Review (1976). He is working on a comparative study of parliament and the church in France and England during the fourteenth and fifteenth centuries. 